\title{
Physalis minima Linn Methanolic Extract Reduces Blood Glucose Level without Compromising Sperm Quality in Normoglycaemic Mice
}

\author{
Dzulsuhaimi Daud ${ }^{1,2^{*}}$, Siti Fatimah Elias ${ }^{2}$, Fatimah Sarah Mohamad Hassan ${ }^{3}$, Mohammad Noor Jalil ${ }^{3}$, Alene Tawang ${ }^{4}$ \\ ${ }^{1}$ Reproductive Biology \& Toxicology Research Group, Pharmaceutical \& Life Sciences Community of Research, Universiti Teknologi MARA, 40450 \\ Shah Alam, Selangor, Malaysia. ${ }^{2}$ School of Biology, Faculty of Applied Sciences, Universiti Teknologi MARA, 40450 Shah Alam, Selangor, Malaysia. \\ ${ }^{3}$ School of Chemistry and Environment, Faculty of Applied Sciences, Universiti Teknologi MARA, 40450 Shah Alam, Selangor, Malay sia. \\ ${ }^{4}$ Department of Biology, Faculty of Science and Mathematics, Universiti Pendidikan Sultan Idris, 35900 Tanjong Malim, Perak, Malaysia.
}

\begin{tabular}{|c|c|}
\hline ARTICLE INFO & ABSTRACT \\
\hline Article history: & \multirow{9}{*}{$\begin{array}{l}\text { Effects of Physalis minima Linn (PML) methanolic extract on blood glucose level and sperm quality of } \\
\text { normoglycaemic mice have been investigated. Twenty four ICR male mice were randomly assigned to four } \\
\text { groups and fed with maintenance diets (commercial rat chow, } 5 \mathrm{~g} / \mathrm{head} / \mathrm{day} \text { and water ad-libitum). Group A } \\
\text { ( } \mathrm{n}=6 \text { ) served as a control and received additional } 2 \mathrm{ml} / \mathrm{kg} \text { bodyweight }(\mathrm{bwt}) \text { of distilled water. Group B, C and D } \\
\text { were supplemented with } 50,100 \text { and } 200 \mathrm{mg} / \mathrm{kg} \text { bwt of PML, respectively. Bodyweight and blood glucose level } \\
\text { were monitored on a weekly basis. After four weeks of treatment, all animals were sacrificed by cervical } \\
\text { dislocation and their epididymis was collected and subjected to sperm analysis. Bodyweight was increased } \\
(\mathrm{p}<0.05 \text { ) over time but no differences ( }>0.05 \text { ) were observed between treatments. B lood glucose was decreased } \\
\text { significantly ( }<0.05 \text { ) in PML treated groups (dose dependent manner) compared to control. Sperm quality was } \\
\text { not affected with PML supplementation. In conclusion, PML methanolic extract exhibit hypoglycaemic effect } \\
\text { without affecting sperm quality in male mice. }\end{array}$} \\
\hline ed on: $13 / 01 / 2016$ & \\
\hline $3 / 2016$ & \\
\hline 016 & \\
\hline Available o & \\
\hline Key words: & \\
\hline Physalis minima, sperm & \\
\hline quality, blood glucose, & \\
\hline diabetes $n$ & \\
\hline
\end{tabular}

\section{INTRODUCTION}

Physalis minima Linn (PML) belongs to the family Solanaceae and commonly known as "Leletup" in Malaysia. This herb is found throughout India, Afghanistan, Africa, Indonesia, Malaysia and Australia (Patel et al., 2011). The flowers are hermaphrodite (have both male and female organs) and pollinated by insects. The fruit is edible, yellowish and encapsulated in papery cover. The infusion of PML is said to relieve pain, lower fever, relieve indigestion, relieve cough with phlegm, be diuretic and relieve oral thrush (Nathiya and Dorcus, 2012). Herbal medicine practitioners in Malaysia have used the plant in combination with other local plants to treat hypertension, diabetes and also as an appetizer. Although the beneficial effects

* Corresponding Author

Dzulsuhaimi Daud, School of Biology, Faculty of Applied Sciences, Universiti Teknologi MARA, 40450 Shah Alam, Selangor, Malaysia. Email:dzuls990@gmail.com of Malaysian PML have been heavily exploited, little scientific research has been conducted on its hypoglycaemic and reproductive toxicity activities. Diabetes mellitus (DM) is characterised by chronic hyperglycaemia caused by defects in insulin secretion, insulin action, or both resulting in impaired function in carbohydrate, lipid and protein metabolism. World Health Organization (WHO) estimates that currently more than 180 million people worldwide have diabetes and it is likely to double by 2030 (Bisla et al., 2014). The complications associated with DM are severe. The illness is one of the main causes of blindness, kidney disease, atherosclerosis, liver disease and a variety of debilitating neuropathies that diminish the quality of life and life expectancy of the patients (Ghate et al., 2014). In the past decade, rigorous research had been conducted to find out the best way to treat DM and to overcome the implications as observed in DM, either by modern or alternative medicine (Sani et al., 2014). Male reproductive toxicology has recently become a rapidly extending area of research and testing (Ajayi and Jegede, 2013). 
Since herbal medicines have recently become a widespread form of therapy, male reproductive toxicity studies should be considered as part of the safety evaluation process of medicinal plants (Kimmel et al., 1995). The male reproductive system is very sensitive to the action of harmful factors, and the exposure to the certain agent can interfere with sexual maturation, the production and transportation of sperm, the spermatogenic cycle, the sexual behaviour and male fertility (Goncalves et al., 2014). As far as our literature survey could ascertain, no attempts have been made to investigate the effect of Malaysian PML on the male reproductive system.

The purposes of the present study were (i) to ascertain the scientific basis for the use of this plant in the management of blood glucose/diabetic (ii) to elucidate whether PML methanolic extract implies reproductive hazards to male reproductive system.

\section{MATERIALS AND METHODS}

\section{Plant materials and methanolic extract preparation}

Fresh wild plants of Physalis minima Linn (PML) were collected from Gomali Estate, Segamat, Johor. The collected plant was authenticated by taxonomist of Herbarium, Universiti Kebangsaan Malaysia and voucher sample number PML-01-MNJ was deposited in our research laboratory. The whole plants (leaves, stems, roots and fruits) were washed, cut into pieces and shade dried at room temperature. The dried plants were subjected to size reduction to a coarse powder using a mechanical grinder (Steel Thomas Wiley Mini Mill 3383L40, USA) and passed through a $150 \mu \mathrm{m}$ metal sieve using Vibrator Sieve Shaker (Retsch, Germany). This powder (10 g) was packed into soxhlet apparatus (Advantec, Japan) and extracted successively with 250 $\mathrm{ml}$ methanol at $63{ }^{\circ} \mathrm{C}$. The extracts were evaporated to dryness under reduced pressure untila semisolid mass was obtained and were stored in airtight containers (Norizzah et al., 2012). The suspensions of the extract were prepared by using physiological saline as a solvent for the experiment.

\section{Animals and experimental design}

Twenty four healthy adult ICR strain male mice, 10 weeks old and weighing about 25-30 g were used for the study. Housed in polypropylene cages and maintained under standard conditions ( $12 \mathrm{~h}$ lights and $12 \mathrm{~h}$ dark cycle). All animals were fed with commercial rat chow (5 g/head/day) and water ad libitum. The animals were randomly divided into four groups of six animals in each group, and received the following treatment daily for four weeks by oral gavage; Group A was administered with 2 $\mathrm{ml} / \mathrm{kg}$ bwt of distilled water and served as a control, Group B was supplemented with $50 \mathrm{mg} / \mathrm{kg}$ bwt of PML, Group C was supplemented with $100 \mathrm{mg} / \mathrm{kg}$ bwt of PML and Group D was supplemented with $200 \mathrm{mg} / \mathrm{kg}$ bwt of PML. The use of animals in this study was monitored by the Research Ethics Committee of the Faculty of Applied Sciences, Universiti Teknologi MARA and approved by the UiTM Research Committee on the Ethical Use of Animals (UiTM Care No. 111/2015). At the end of the experimental period, all mice were sacrificed by cervical dislocation and the carcasses were collected by a commercial company appointed by the Faculty of Applied Sciences, Universiti Teknologi MARA for disposal.

\section{Bodyweight measurement and estimation of blood glucose}

Changes in bodyweight of all mice were recorded on a weekly basis using a precision scale (Kern \& Sohn, Germany) to the nearest gram. Meanwhile, blood sample was collected from overnight fasting mouse by tail vein puncture method. Blood glucose level was estimated using an Accu-Check Advantage II Electronic Glucometer (Roche Diagnostics, Germany) and was made weekly throughout the period of study.

\section{Sperm quality analysis}

At the end of the experimental duration, all mice were sacrificed by cervical dislocation. Cauda epididymis was separated and minced using a scissors in a petri dish containing $1 \mathrm{ml}$ phosphate buffer saline (Abu et al., 2013). The debris was removed and the sperm suspension was incubated in a $\mathrm{CO}_{2}$ incubator (Memmert, Germany) for 15 minutes at $37^{\circ} \mathrm{C}$ and $5 \%$ $\mathrm{CO}_{2}$ to allow the motile sperm to swim up (Liu et al., 2012). The sperm suspension was subjected to the determination of sperm count, sperm motility and sperm morphology according to WHO criteria (NAFA, 2002). Sperm count determination was carried out using the Makler Counting Chamber according to manufacturer's instructions (Sefi Medical Instruments, USA). Meanwhile, sperm motility evaluation was assessed by visual estimation under the light microscope (Olympus CX21, Japan). For the purpose of this study, at least 100 sperm were observed and classified as either motile or non-motile (Daud et al., 2015). Sperm morphology determination was carried out by means of the giemsa staining method (Casarett, 1953). At least 100 sperm were classified as either normal or abnormal morphology (head, midpiece and tail anomalies). Head anomalies: detached, tapered, microcephalous, macrocephalous, multiple or absent acrosome. Midpiece anomalies: cytoplasmic droplet, thin or bent. Tail anomalies: absent, coiled or multiple.

\section{Statistical analysis}

Results are presented as means \pm SEM $(n=6)$. Data being collected at several time intervals were analysed by repeated measures of ANOVA. Probability of $p<0.05$ was considered to be significant.

\section{RESULTS AND DISCUSSION}

\section{Bodyweight}

Bodyweight of mice in all groups significantly $(\mathrm{p}<0.05)$ increased over time. However, the bodyweight was not significantly affected ( $>0.05)$ by entire dosages of Physalis minima Linn (PML) methanolic extract (Figure 1).Bodyweight of normoglycaemic mice supplemented with 50, 100 and $200 \mathrm{mg} / \mathrm{kg}$ 
bwt of PML methanolic extract increased by24.49, 18.16 and $16.64 \%$, respectively, following four weeks of experimental period. All groups increased their bodyweight during the experimental period indicating that PML supplementation allowed the growth of the animals. In the current study, we do not measure the feed intake but these results convinced us to speculate that feed intake was not affected by PML consumption. Perk et al., (2013) reported that the percentage of bodyweight changes did not differ significantly in between control rats and rats supplemented with $1000 \mathrm{mg} / \mathrm{kg}$ of Physalis peruviana. In addition to, Nabila (2012) documented that rats fed diet contains Physalis extract showed a significant increase in bodyweight gain and food intake.

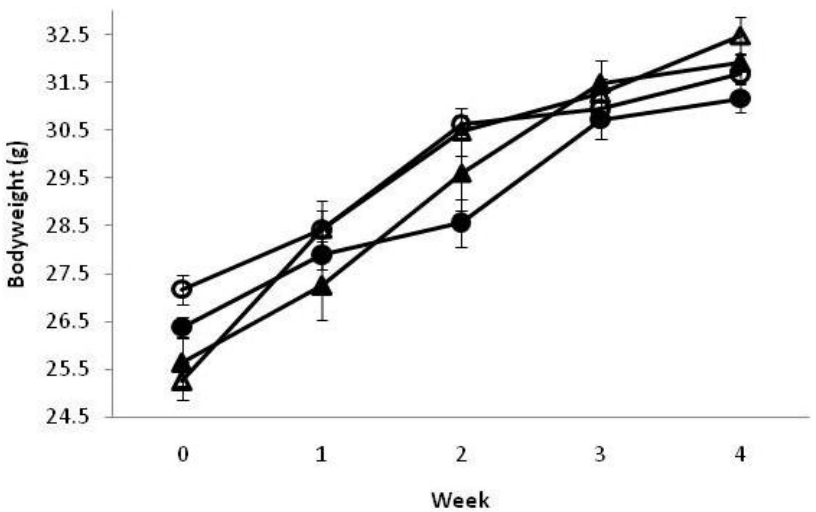

Fig. 1:Bodyweight of mice fed with maintenance diets and supplemented orally with2 $\mathrm{ml} / \mathrm{kg}$ bwt of distilled water (Group A, $\Delta$ ), $50 \mathrm{mg} / \mathrm{kgbwt}$ of PML (Group B, $\mathbf{\Delta}$ ), $100 \mathrm{mg} / \mathrm{kg}$ bwt of PML (Group C, ○) and $200 \mathrm{mg} / \mathrm{kg}$ bwt of PML (Group D, •). Values are presented as mean \pm standard error of mean $(n=6)$.

\section{Blood glucose level}

Blood glucose level significantly $(\mathrm{p}<0.05)$ decreased in normoglycaemic mice supplemented with PML methanolic extract in dose dependent manner compared to control (Figure 2). Normoglycaemic mice supplemented with 50,100 and $200 \mathrm{mg} / \mathrm{kg}$ PML methanolic extracts showed 21.54, 32.81 and $33.87 \%$ of reduction in blood glucose level, respectively. Previous authors reported that, PML aqueous extract significantly decreased the blood glucose level inalloxan-induced diabetic rats (Sucharita and Estari, 2013). The obtained results also were agreed with Estakhr and Javdan (2011) who recorded that Physalis sp.ethanolic extract normalized blood glucose level in alloxan-induced diabetic rats. Chothani and Vaghasiya (2012) documented that, the PML ethanolic extract possess in-vitro inhibitory activity on intestinal alpha glucosidase maltase. Nathiya and Dorcus (2012) demonstrated that saponins was present in PML methanolic extract. It was studied that saponins can exhibit antihyperglycaemic properties through modulation of calcium channel and can stimulate insulin secretion by the pancreas (Koneri et al., 2014). Another mechanism of saponins as an anti-hyperglycaemic agent is through stimulation of 5-adenosine monophosphate activated protein kinase signals to stimulate glucose uptake in skeletal muscles, reduce hepatic glucose production and reduce fatty acid oxidation in adipose tissues (Coughlan et al., 2014). In the current study, there is no attempt was made to ascertain the mechanism of the observed hypoglycaemic activity. The possible mechanisms of PML action may be by promoting the insulin release from the pancreas $\beta$-cells (Zhang et al., 2012), action by insulin like molecules (Sucharita and Estari, 2013) or enhancing hepatic glycogen formation (Yin et al., 2002). Further studies are recommended to find out the possible PML mechanism of action.

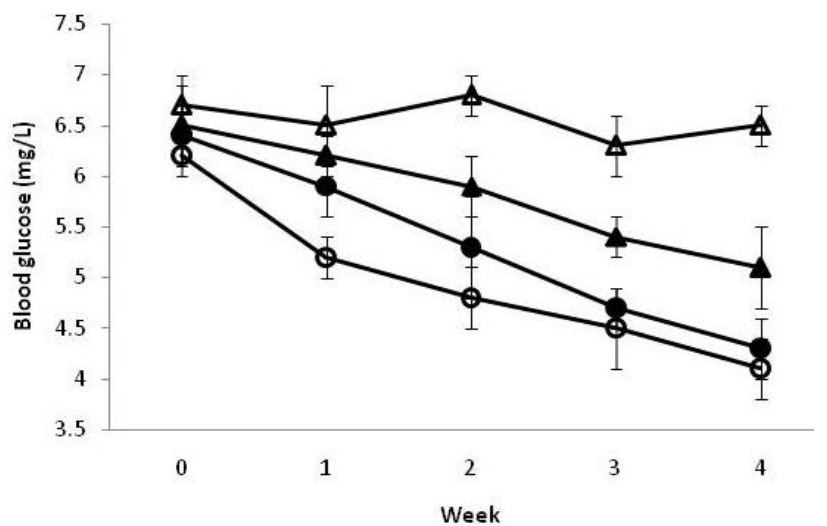

Fig. 2: Blood glucose level in mice fed with maintenance diets and supplemented orally with $2 \mathrm{ml} / \mathrm{kg}$ bwt of distilled water (Group A, $\Delta$ ), 50 $\mathrm{mg} / \mathrm{kg}$ bwt of PML(Group B, $\boldsymbol{\Delta}$ ), $100 \mathrm{mg} / \mathrm{kg}$ bwt of PML (Group C, ○) and $200 \mathrm{mg} / \mathrm{kg}$ bwt of PML (Group D, •). Values are presented as mean \pm standard error of mean $(n=6)$.

\section{Sperm quality}

Sperm quality (sperm count, sperm mortality and sperm morphology) was not affected by PML methanolic extract (Table 1).

Table 1: Sperm quality of mice fed with maintenance diets and supplemented orally with $2 \mathrm{ml} / \mathrm{kg}$ bwt of distilled water (Group A), supplemented with 50 $\mathrm{mg} / \mathrm{kg}$ bwt of PML (Group B), supplemented with $100 \mathrm{mg} / \mathrm{kg}$ bwt of PML (Group C) and supplemented with $200 \mathrm{mg} / \mathrm{kg}$ bwt of PML (Group D). Values are presented as mean \pm standard error of mean $(n=6)$.

\begin{tabular}{ll}
\hline $\mathbf{A B}$ & $\mathbf{C D}$ \\
\hline Sperm count $\left(10^{6} / \mathrm{ml}\right)$ & $34.3 \pm 1.3^{\mathrm{a}} 34.7 \pm 2.4^{\mathrm{a}} 33.5 \pm 1.5^{\mathrm{a}} 35.2 \pm 3.1^{\mathrm{a}}$ \\
Non-motile sperm $(\%)$ & $28.6 \pm 2.6^{\mathrm{a}} 31.4 \pm 2.3^{\mathrm{a}} 30.3 \pm 3.1^{\mathrm{a}} 30.9 \pm 1.9^{\mathrm{a}}$ \\
Abnormal sperm $(\%)$ & $35.7 \pm 1.5^{\mathrm{a}} 34.6 \pm 1.7^{\mathrm{a}} 37.3 \pm 2.3^{\mathrm{a}} 36.9 \pm 0.9^{\mathrm{a}}$ \\
${ }^{\mathrm{a}}$ Superscript in the same row shows no significant difference $(\mathrm{p}>0.05)$
\end{tabular}

Taken together, these results showed that the oral treatment with different dosages of PML methanolic extract (50, 100 and $200 \mathrm{mg} / \mathrm{kg}$ ) for four weeks induces no toxic effects in the male reproductive system. It is well established that motile sperm in sufficient concentration and free from abnormalities are highly correlated with fertility because sluggishly motile or immotile sperm are not likely to penetrate the cervical mucus and fertilize the ova (Abu et al., 2013). In contrast, Mohana and Purushotaman (1981) demonstrated that Physaline-B, an active compound isolated from PML, shows anti-fertility activity. Perhaps, this can be explained by the different types of extract used in the experiments. The current study used methanolic crude extract meanwhile Mohana and Purushotaman (1981) utilised pure active compound. Interestingly, Chothani and Vaghasiya (2012) reported that quercetin that have positive effects on sperm was present in PML. The effects of quercetin on sperm quality depend on the 
dose and duration of treatment. According to Taepongsorat et al., (2008), positive effects of quercetin on sperm quality were found only at a dose of $270 \mathrm{mg} / \mathrm{kg}$ of bodyweight and for the duration of at least 14 days. The current study suggest that the amount of quercetin and Physaline-B in PML methanolic extract (50, 100 and $200 \mathrm{mg} / \mathrm{kg}$ of crude extract) insufficient to alter sperm quality of normoglycaemic mice.

\section{CONCLUSIONS}

In conclusion, the present study provided scientific validation of the folklore use of the Physalis minima Linn (PML) and suggested that this plant has promising therapeutic activity for the management of blood glucose. Current data also suggested that, administration of PML does not have an evident effect on sperm quality of normoglycaemic mice.

\section{ACKNOWLEDGEMENT}

This work was financially supported by The Faculty of Applied Sciences and Institute of Research Management and Innovation (IRMI), UniversitiTeknologi MARA through the Research Intensive Faculty Grant (600-RMI/DANA 5/3/RIF634/2012) and Ministry of Higher Education, Malaysia through the Fundamental Research Grant Scheme (600-RMI/FRGS 5/3 64/2013).

\section{CONFLICT OF INTEREST AND AUTHOR'S CONTRIBUTION}

The authors declare that there is no conflict of interests regarding the publication of this paper. All authors were involved in the writing, revision and final approval of the paper.

\section{REFERENCES}

Abu AH, Amuta PO, Buba E, Inusa TR. Evaluation of antispermatogenic effect of Garcinia kola seed extract in Albino rats. Asian Pac J Reprod, 2013;2:15-18.

Ajayi AF, Jegede AI. Reproductive profile of male Wistar rats treated with graded doses of aqueous extract of Titoniadiversifolia leaf. World J Life Sci Med Res, 2013;2:48-53.

Bisla G, Choudhary S, Choudhary V. Evaluation of the nutritive and organolepticvalues of food products developed by incorporated Catharanthusroseusfresh leaves explore their hypoglycaemic potential. The Scientific World J, 2014; doi/org/10.1155/2014/304120.

Casarett GW. A one solution stain for spermatozoa. Stain Tech, 1953;28:125-127.

Chothani DL, Vaghasiya HU. A phyto-pharmacological overview on Physalis minima Linn. Indian J Nat Prod Resour, 2012;3:477482.

Coughlan KA, Valentine RJ, Ruderman NB, Saha AK. AMPK activation, a therapeutic target for type 2 diabetes. Diabetes Metab Syndr Obes, 2014;7:241-53.

Daud D, Gan NNMS, Ali MTM, Tawang A. The effect of Melaleucacajuputi methanolic leaves extract on body growth, puberty and sperm qualityof juvenile male rats. Biotech An Indian J, 2015;11:115-119.
Estakhr J, Javdan N. The effects of hydro alcoholic extract of Physalisalkekegi in alloxan induced diabetic rats. Pharmacologyonline, 2011;2:874-878.

Ghate R, Patil VP, Hugar S, Matha NH, Kalyane NV. Antihyperglycemic activity of Areca catechu flowers. Asian Pac J Trop Dis, 2014;4:S148-S152.

Goncalves ES, Silva JR, Gomes CL, Nery MBL. Effects of the oral treatment with Copaiferamultijuga oil on reproductive performance of male Wistar rats. Rev Bras Farmacogn, 2014;24:355-362.

Kimmel GL, Clegg ED, Crisp TM. In Reproductive Toxicity, Eds. R.J. Witorsch, Raven Press, 1995; pp.75-98.

Koneri RB, Samaddar S, Ramaiah CT. Antidiabetic activity of a triterpenoidsaponin isolated from MomordicacymbalariaFenzl. Indian J ExpBiol, 2014;52:46-52.

Liu J, Lee GY, Lawitts JA, Toner M, Biggers JD. Technical Note: Mice produced by intracytoplasmic sperm injection using a modified conventional method. J AnimSci, 2012;90:3739-3742.

Mohana K, PurushothamanKK. Antifertility properties of Physalis minima. Bull Medico Ethno-Bot Res, 1981;2:135-143.

Nabila MR. Effect of Physalis and Choline on lipid profile and antioxidant activity in hepatic toxicity rats. Aust J Basic ApplSci, 2012;6:654-660.

NAFA. Manual on basic semen analysis.ESHRE Press, 2002; pp. 1-33.

Nathiya M, Dorcus D. Preliminary phytochemical and antibacterial studies on Physalis minima Linn. Inter J CurrSci, 2012;24-30.

Norizzah JS, Norizan A, Ruzaina SAS, Dzulsuhaimi D, NurulHidayah MS. Cytotoxicity activity and reproductive profiles of male rats treated with methanolic extracts of Ficusdeltoidea. Res J Med Plant, 2012;6:197-202.

Patel T, Shah K, Jiwan K, Shrivastava N. Study on the antibacterial potential of Physalis minima Linn. Indian J Pharm Sci, 2011;73:111-115.

Perk BO, Ilgin S, Atli O, Duymus HG, Sirmagul B. Acute and subchronic toxic effects of the fruits of Physalisperuviana L. Evid Based Complement Alternat Med, 2013; doi.org/10.1155/2013/707285.

Sani NFA, Belani LK, Sin CP, Rahman SNAA, Das S, Chi TZ, Makpol S, Yusof YAM. Effect of the combination of gelam honey and ginger on oxidative stress and metabolic profile in streptozotocin-induced diabetic Sprague-Dawley rats. BioMed Res Intl, 2014; doi.org/10.1155/2014/160695

Sucharita E, Estari M. Evaluation of antidiabetic activity of medicinal plant extracts used by tribal communities in rural areas of Warangal district, Andhra Pradesh, India. Bio Med, 2013;5:20-25.

Taepongsorat L, Tangpraprutgul P, Kitana N, Malaivijitnond S. Stimulating effects of quercetin on sperm quality and reproductive organs in adult male rats. Asian J Androl, 2008;10:249-58.

Yin J, Hu R, Chen M. Effects of berberine on glucose metabolism in vitro. Metabolism, 2002;51:1439-1443.

Zhang Y, Shi J, Zhao Y, Cui H, Cao C, Liu S. An investigation of the anti-diabetic effects of an extract from Cladoniahumilis. Pak J Pharm Sci, 2012;25:509-512.

\section{How to cite this article:}

Daud D, Elias SF, Hassan FSM, Jalil MN, Tawang A. Physalis minima Linn Methanolic Extract Reduces Blood Glucose Level without Compromising Sperm Quality in Normoglycaemic Mice. J App Pharm Sci, 2016; 6 (06): 008-011. 